\title{
OPTIMASI PRODUKSI MALTODEKSTRIN BERBASIS PATI SAGU MENGGUNAKAN $\alpha$-AMILASE DAN METODE SPRAY DRYING
}

\author{
Vioni Derosya dan Anwar Kasim \\ Program Studi Teknologi Hasil Pertanian, Fakultas Teknologi Pertanian, Universitas Andalas \\ Email: vioniderosya@fateta.unand.ac.id
}

\begin{abstract}
ABSTRAK
Sagu (Metroxylon sagu Rottb) merupakan sumber pati melimpah di Indonesia namun belum dimanfaatkan secara optimal. Di satu sisi, Indonesia masih mengimpor pati termodifikasi termasuk maltodekstrin yang berbahan dasar pati untuk memenuhi kebutuhan industri terutama obat-obatan dan pangan. Produksi maltodekstrin dari pati sagu diharapkan dapat mendukung pengembangan produk turunan pati berbasis tanaman lokal. Pada penelitian ini, maltodekstrin berbasis pati sagu diproduksi menggunakan spray dryer dengan konsentrasi $10 \%, 20 \%$ dan 30\% sedangkan enzim alfa amilase yang digunakan adalah $0,05 \mathrm{ml}$ dan $0,1 \mathrm{ml}$. Tujuan penelitian ini adalah untuk mengetahui variasi konsentrasi substrat pati sagu dan konsentrasi enzim yang menghasilkan maltodekstrin dengan kadar air, rendemen, viskositas, dan gula reduksi terbaik. Kadar air dari maltodekstrin berbasis pati sagu berkisar dari 3,46$5,68 \%$ dengan rendemen berkisar 17,84 - 41,36 \%, viskositas 0-32 BU, dan gula pereduksi berkisar antara $0,73-1,47 \%$.

Kata kunci- Alfa amilase, Maltodekstrin, Pati sagu, Spray dryer
\end{abstract}

\section{PENDAHULUAN}

Sagu (Metroxylon sagu Rottb) merupakan salah satu tanaman penghasil pati dengan ketersediaan yang melimpah di Indonesia. Potensi sagu di Indonesia menempati $\pm 50 \%$ potensi sagu dunia dengan produktivitas 25 ton/ha setiap tahunnya (Karim et al. 2008; Bujang, 2014). Namun, jumlah tersebut belum dimanfaatkan secara optimal. Pemanfaatan sagu masih rendah yaitu 15-20\% ditandai dengan banyaknya tanaman sagu layak panen namun rusak karena tidak dipanen (Suryana, 2007).

Di satu sisi, perkembangan industri pangan dan obat-obatan membutuhkan pati sebagai bahan pengental atau bahan pengisi. Agar dapat digunakan dalam industri, modifikasi pati alami perlu dilakukan terkait sifat alami pati seperti susah larut dalam air dingin, gel tidak bening dan tidak stabil, membutuhkan suhu yang tinggi untuk proses pemasakan (Triyono, 2006). Maltodekstrin adalah salah satu produk modifikasi pati termasuk pati sagu dengan cara dihidrolisis secara enzimatis atau hidrolisis asam. Indonesia sendiri saat ini masih mengimpor pati termodifikasi termasuk maltodekstrin untuk memenuhi kebutuhan industri terutama obat-obatan dan pangan dengan nilai impor tahun 2015 adalah US\$5.2 juta ( Kemenperin, 2016).

Maltodekstrin komersial dan beberapa hasil penelitian menggunakan pati jagung dan tapioka sebagai bahan baku. Namun, penggunan jagung dan singkong sebagai energi alternatif pun sangat luas (Moore et al., 2005; Lambri et al.,2014). Hal ini berbeda dengan sagu yang masih berpeluang untuk dikembangkan di industri pangan. Selain itu, sagu memiliki potensi rendemen 3-4 kali lebih besar rendemen dibandingkan jagung (Ishizaki et al. 1997 dalam Bujang, 2014). Telah dikenalnya teknik ekstraksi pati sagu oleh masyarakat sejak lama juga memberikan peluang pengembangan dan penggunaan pati sagu sebagai bahan baku industri.

Penelitian ini menggunakan enzim untuk menghidrolisis pati sagu dalam pembuatan maltodekstrin terkait peruntukan produk pada industri pangan. Hal ini dijelaskan Hermiati et al. (2010) yang memilih hidrolisis enzim untuk mengurangi dampak lingkungan dan keamanan pangan dari proses asam seperti yang digunakan. Optimasi pada penggunaan enzim perlu dilakukan untuk efisiensi biaya. Untuk itu, penelitian ini bertujuan untuk variasi konsentrasi substrat pati sagu dan konsentrasi enzim yang menunjukkan hasil terbaik terhadap rendemen dan kualitas maltodekstrin yang dihasilkan 


\section{METODOLOGI PENELITIAN}

\section{A. Bahan dan Alat}

Bahan yang digunakan dalam penelitian ini adalah pati sagu kering dari jenis Metroxylon sagu yang didapat dari pengolah sagu di daerah Koto Marapak, Kota Pariaman. Enzim yang digunakan adalah $\alpha$-amilase dari Aspergillus oryzae dari NOVO Enzyme dengan aktivitas enzim $800 \mathrm{FAU} / \mathrm{g}$ (Fung.Alpha Amylase units). Bahan-bahan kimia yang digunakan untuk penelitian ini antara lain larutan DNS dan akuades. Untuk alat yang digunakan dalam penelitian ini adalah adalah spray dryer (Amfield FT300), Brabender (Micro Visco-Amylo-Graph), mikropipet (Transferpette), timbangan analitik (Kern PCB), penangas, bath shaker dengan termometer, timbangan kasar, oven, cawan aluminium, dan alat gelas.

\section{B. Prosedur Percobaan}

Suspensi pati dengan konsentrasi 10,20 , dan $30 \% \mathrm{~b} / \mathrm{v}$ digelatinisasi pada suhu $80^{\circ} \mathrm{C}$ dan ditambah enzim $\alpha$-amilase $(0,05$ dan $0,1 \mathrm{ml})$ per $100 \mathrm{ml}$ sampel. Hidrolisis dilakukan selama 30 menit pada suhu $90^{\circ} \mathrm{C}$. Pengeringan dilakukan menggunakan spray dryer (Amfield FT300) pada suhu $160^{\circ} \mathrm{C}$.

Kadar air dari produk maltodekstrin dilakukan dengan metode oven (AOAC, 1998). Rendemen maltodekstrin merupakan bobot hasil hidrolisat pati yang telah dikeringkan dengan spray dryer dibagi dengan bobot pati sebelum terhidrolisis yang dinyatakan dalam persen. Pengukuran viskositas menggunakan Brabender dilakukan dengan melarutkan maltodekstrin dengan air dan digelatinisasi. Penentuan gula pereduksi dilakukan dengan DNS (dinitro salicilic acid) dengan standar glukosa 0, 100, 200, 300, 400, dan 500 ppm.

\section{HASIL DAN PEMBAHASAN}

\section{A. Kadar Air}

Kadar air dari maltodekstrin berbasis pati sagu berkisar dari 3,46-5,68\%. Kadar air tertinggi adalah pada maltodekstrin dari pati sagu $30 \%$ dengan penambahan enzim $0,05 \mathrm{ml} / 100 \mathrm{ml}$. Hal ini terkait dengan tingginya konsentrasi pati sehingga lebih padat dan sukar dikeringkan. Namun, penambahan enzim $0,1 \mathrm{ml} / 100 \mathrm{ml}$ pada semua konsentrasi pati dalam pembuatan maltodekstrin menghasilkan produk dengan kadar air lebih rendah dibandingkan dengan penambahan enzim pada konsentrasi 0,05 $\mathrm{ml}$.

Setelah dihidrolisis, maltodekstrin cair harus dikeringkan agar dapat mudah disimpan dan digunakan. Berdasarkan SNI 01-2593 tahun 1992 terkait syarat mutu dekstrin, kadar air maksimum dari produk ini adalah $11 \%$. Adapun kadar air dari produk maltodekstrin pada berbagai konsentrasi pati sagu dan konsentrasi enzim ditampilkan pada Gambar 1 berikut.

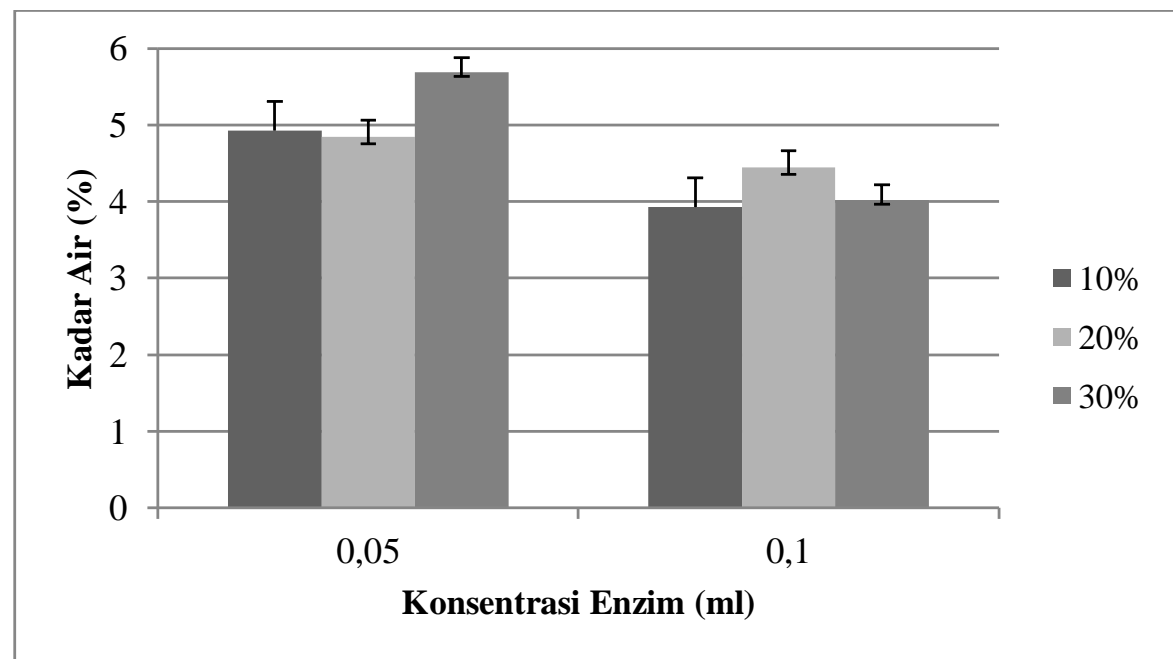

Gambar 1. Kadar Air Produk Maltodekstrin dari Pati Sagu dengan Konsentrasi 10, 20 dan 30\% 


\section{B. Rendemen}

Penambahan enzim yang sesuai pada konsentrasi pati sagu menghasilkan maltodekstrin dengan rendemen yang lebih tinggi. Rendemen maltodekstrin berbasis pati sagu berkisar 17,84 - 41,36\%. Adapun rendemen tertinggi terdapat pada maltodesktrin berbahan baku pati sagu $10 \%$ dengan enzim alfa amilase $0,05 \mathrm{ml} / 100 \mathrm{ml}$ suspensi sedangkan rendemen terendah dihasilkan oleh maltodesktrin berbahan baku pati sagu dengan konsentrasi 30\% dengan enzim alfa amilase $0,1 \mathrm{ml} / 100 \mathrm{ml}$ suspensi.

Adapun konsentrasi pati sagu yang lebih tinggi seperti konsentrasi 30\% namun menghasilkan rendemen maltodekstrin yang rendah mengindikasikan bahwa tidak optimalnya kinerja enzim dalam memecah ikatan pati pada suspensi. Di satu sisi, konsentrasi $10 \%$ memberikan rendemen lebih tinggi daripada maltodekstrin yang terbuat dari pati sagu dengan konsentrasi 20\% dan 30\%. Perbandingan rendemen dari berbagai perlakuan konsentrasi pati sagu dan konsentrasi enzim ditampilkan pada Gambar 2 berikut ini.

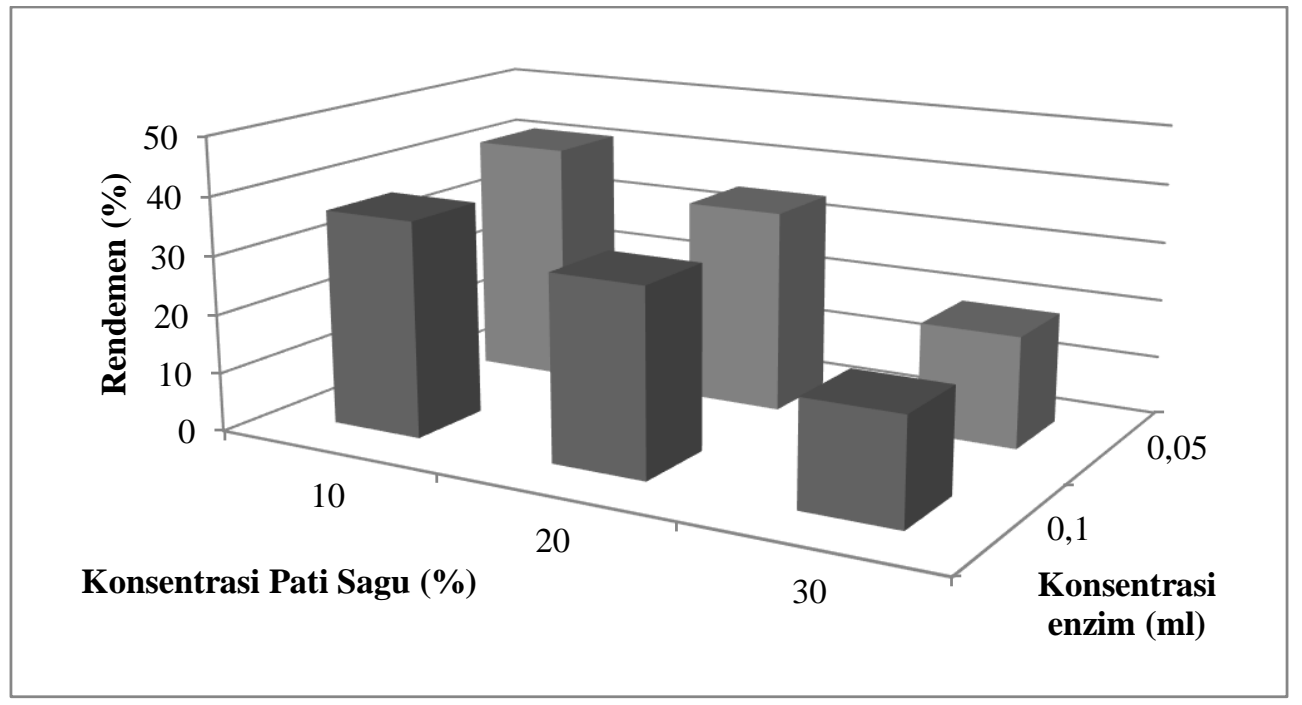

Gambar 2. Rendemen Produk Maltodekstrin dari Pati Sagu Konsentrasi 10, 20 dan 30\%

\section{Viskositas}

Viskositas merupakan perubahan sifat fisik dari pati alami seperti sagu saat mengalami hidrolisis. Dokic et al. (2004) menjelaskan bahwa viskositas maltodekstrin tidak dipengaruhi oleh bahan baku patinya berasal, namun dipengaruhi oleh ukuran molekul maltodekstrin yang erat kaitannya dengan nilai dextrose equivalent-nya. Terkait dengan kegunaan maltodekstrin, viskositas produk yang diharapkan adalah produk dengan viskositas yang rendah walaupun telah melewati proses pada temperatur tinggi.

Dari hasil pengamatan terhadap viskositas produk pada berbagai konsentrasi pati sagu, nilai viskositas 0 BU dicapai oleh maltodekstrin dari konsentrasi pati sagu $20 \%$ yang dihidrolisis oleh $0,1 \mathrm{ml}$ enzim per $100 \mathrm{ml}$ larutannya dan juga pada pati sagu konsentrasi $30 \%$ dengan $0,05 \mathrm{ml}$ enzim per 100 $\mathrm{ml}$ larutan. Hal ini juga menunjukkan perlakuan hidrolisis dan enzim yang menurunkan viskositas pati sagu dengan nilai viskositas awal yaitu 766 BU seperti yang ditampilkan pada Tabel 1 berikut ini.

Tabel 1. Viskositas Pati Sagu dan Produk Maltodekstrin pada

Berbagai Konsentrasi Pati Sagu dan Penambahan Enzim

\begin{tabular}{|c|c|}
\hline Perlakuan & Viskositas (Brabender Unit) \\
\hline Pati sagu & 766 \\
\hline $10 \% 0,05 \mathrm{ml} / 100 \mathrm{ml}$ & 19 \\
\hline $10 \% 0,1 \mathrm{ml} / 100 \mathrm{ml}$ & 13 \\
\hline $20 \% 0,05 \mathrm{ml} / 100 \mathrm{ml}$ & 32 \\
\hline $20 \% 0,1 \mathrm{ml} / 100 \mathrm{ml}$ & 0 \\
\hline $30 \% 0,05 \mathrm{ml} / 100 \mathrm{ml}$ & 0 \\
\hline $30 \% 0,1 \mathrm{ml} / 100 \mathrm{ml}$ & 30 \\
\hline
\end{tabular}




\section{Gula Pereduksi}

Gula reduksi dan nilai DE pada produk maltodekstrin mempengaruhi kelas kualitas dari produk maltodekstrin. Hobbs (2009) menjelaskan lebih lanjut bahwa nilai DE dari produk maltodekstrin haruslah kurang dari 20. Gula reduksi mengindikasikan hasil hidrolisis pati menjadi gula oleh enzim alfa amilase. Gula reduksi dari beberapa konsentrasi pati sagu yang dihasilkan berkisar antara 19603135 ppm sedangkan nilai DE berkisar antara 0,73-1,47 \% seperti yang ditampilkan pada Tabel 2.

Perbedaan nilai DE yang dihasilkan terkait dengan sifat fungsional fisik dan biologis pada maltodekstrin sehingga mempengaruhi tujuan penggunaan dari maltodekstrin (Marchall et al., 1996). Sebagai contoh, maltodekstrin dengan nilai DE yang rendah dapat digunakan sebagai lemak tiruan dalam produk pangan karena mempunyai sifat gel yang tinggi dan thermoreversible (Roper, 1996).

Tabel 2. Gula Reduksi dan DE (dextrose equivalent) Produk Maltodekstrin pada Berbagai Konsentrasi Pati Sagu dan Penambahan Enzim

\begin{tabular}{|c|c|c|}
\hline Perlakuan & Gula Reduksi (ppm) & DE (\%) \\
\hline $10 \% 0.05 \mathrm{ml} / 100 \mathrm{ml}$ & $1960 \pm 127,28$ & 0.85 \\
\hline $10 \% 0.1 \mathrm{ml} / 100 \mathrm{ml}$ & $3135 \pm 120,21$ & 1.47 \\
\hline $20 \% 0.05 \mathrm{ml} / 100 \mathrm{ml}$ & $2840 \pm 113,14$ & 0.93 \\
\hline $20 \% 0.1 \mathrm{ml} / 100 \mathrm{ml}$ & $2770 \pm 367,70$ & 0.85 \\
\hline $30 \% 0.05 \mathrm{ml} / 100 \mathrm{ml}$ & $2725 \pm 49.50$ & 1.32 \\
\hline $30 \% 0.1 \mathrm{ml} / 100 \mathrm{ml}$ & $2920 \pm 56,57$ & 0.73 \\
\hline
\end{tabular}

\section{KESIMPULAN}

Maltodekstrin dapat diproduksi dari pati sagu yang memiliki nilai ekonomi yang masih rendah. Maltodekstrin berbasis pati sagu diproduksi dengan bantuan enzim alfa amilase dan dikeringkan menggunakan metode spray dryer. Beberapa konsentrasi pati sagu yang digunakan adalah $10 \%, 20 \%$ dan 30\% dengan enzim alfa amilase $0,05 \mathrm{ml}$ dan $0,1 \mathrm{ml}$. Perbedaan karakteristik dari maltodekstrin yang dihasilkan dipengaruhi oleh konsentrasi pati sagu yang digunakan sehingga memiliki sifat yang bervariasi. Maltodekstrin berpeluang untuk diproduksi dengan konsentrasi pati sagu yang lebih tinggi dan atau penambahan enzim yang lebih rendah.

\section{UCAPAN TERIMAKASIH}

Ucapan terimakasih penulis sampaikan kepada Fakultas Teknologi Pertanian, Universitas Andalas yang telah memfasilitasi dalam pendanaan penelitian ini (DIPA FATETA 2016).

\section{DAFTAR PUSTAKA}

Abd Aziz S. 2002. Review: Sago Starch and Its Utilization. J.Bioscience and Bioengineering 94(6): 526-529

Aiyer, PV. 2005. Amylases and Their Applications. African Journal of Biotechnology Vol 4 (13): 15251529

AOAC. 1999. Official Methods of Analysis of Association of Analitycal Chemist. New York.

Bujang K. 2014. Sago: A food and fuel alternative. https://www.researchgate.net/publication/263351072_SAGO_A_FOOD_AND_FUEL_ALT ERNATIVE [diakses pada 13 Maret 2016]

Chiu C, Solarek D. 2009. Modification of Starch dalam BeMiller J, Whistler R (Ed). 2009. Starch: Chemistry and Technology. Elsevier. US

Direktorat Jenderal Perkebunan Kementerian Pertanian. 2013. Pedoman Teknis Pengembangan Tanaman Sagu Tahun 2014. http://ditjenbun. deptan. go. id/tinymcpuk/gambar/file/Pedoman\%20Teknis\%20Pengembangan\%20Tanaman\%20Sagu.p $d f$ [diakses pada 13 Maret 2016]

Dokic L, Jakovljevic J, Dokic P. 2004. Relation Between Viscous Characteristics and Dextrose Equivalent of Maltodextrins. Starch 56: 520-525. 
Flach M. 1997. Sago Palm Metroxylon Sagu Rottb. Promoting the Concervation and Use of Underutilized and Negleted Crops. Institute of Plant Genetics and Crop Plant Research. Italy

Hermiati E, Mangunwidjaja D, Sunarti TC, Suparno O, Prasetya B. 2010. Pemanfaatan Biomassa Lignoselulosa Ampas Tebu untuk Produksi Bioetanol. Jurnal Litbang Pertanian 29 (4): 121130.

Hobbs L. 2009. Sweeteners From Starch: Production, Properties and Uses dalam BeMiller J, Whistler $R(E d)$. 2009. Starch: Chemistry and Technology. Elsevier. US

Kementerian Perindustrian. 2016. Perkembangan Impor Komoditi Hasil Industri dari Negara Tertentu. http://www.kemenperin.go.id/statistik/query_komoditi.php?komoditi=dextrin\&negara=\&jen is=\&action=Tampilkan. [diakses pada 13 Maret 2016]

Long JE. 1985. US Market for Starch-Based Products dalam Van Beynum GMA, Roels JA. 1985. Starch conversion technology. Marcel Dekker. New York

Marchal LM, HH Beefthink, J Tramper. 1999. Towards a Rational Design of Commercial Maltodextrin. J. Trends in Food Science and Technology, 10. 345-355.

Moore GRP, do Canto LR, Armante ER. 2005. Cassava and Corn Starch in Maltodextrin Production. Quim. Nova 28: 596-600.

Robyt JF. 2009. Enzymes and Their Action On Starch dalam BeMiller J, Whistler R (Ed). 2009. Starch: Chemistry and Technology. Elsevier. US

Roper H. 1996. Starch: Present Use and Future Utilization in Beckum et l (Eds). Carbohydrates as organic raw materials III. VCH Publisher. Weinheim

Standar Nasional Indonesia (SNI). 1995. Pati Sagu. SNI 01-3729-1995. Pusat Standardisasi Industri. Departemen Perindustrian.

Standar Nasional Indonesia (SNI). 1992. Dekstrin. SNI 01-2593. Pusat Standardisasi Industri. Departemen Perindustrian.

Sutanto AI. 2001. Pemanfaatan Pati Sagu sebagai Bahan Baku Pembuatan Dekstrin secara Enzimatis. Skripsi. Fateta IPB. Bogor

Suryana A. 2007. Arah dan Strategi Pengembangan Sagu di Indonesia. Prosiding. Lokakarya Pengembangan Sagu di Indonesia, 25-26 Juli 2007, Batam.

Triyono A. 2006. Upaya Memanfaatkan Umbi Talas (Colocasia esculenta) sebagai Sumber Bahan Pati pada Pengembangan Teknologi Pembuatan Dekstrin. Seminar Nasional Iptek Solusi Kemandirian Bangsa Bidang Industri: 97-103. UII. Yogyakarta

Tyanjani EF, Yunianta. 2015. Pembuatan Dekstrin dari Pati Sagu (Metroxylon sagu Rottb) dengan Enzim $\beta$-amilase terhadap Sifat Fisiko Kimia. J.Pangan dan Agroindustri 3 (3): 1119-1127 